\title{
Courts reject DNA fingerprinting, citing controversy after NAS report
}

Washington. Four months after the National Academy of Sciences (NAS) released a report intended to end the controversy over DNA forensic fingerprinting, the situation is as muddled as ever. At least three state courts have ruled that DNA evidence is inadmissible despite the report's conclusion that it should be accepted. The situation has deteriorated to the point where one DNA fingerprinting company - the Maryland-based Cellmark Diagnostics Inc. - would like the NAS panel to clarify its conclusions.

The courts have rejected DNA evidence for reasons not foreseen when the report was released in April (see Nature 356, 552; 1992). One of its recommendations was for better laboratory quality-control standards and certification procedures, and some DNA fingerprinting critics have argued (persuasively enough to appear on the front page of the New YorkTimes in an article that was essentially retracted the following day) that DNA evidence should be inadmissible until such procedures are established.

But the issue that most bothered the courts relates to statistics, not standards. The California Court of Appeals, the Massachusetts Supreme Judicial Court and the US District Court of Guam have all ruled (citing the NAS report and the accompanying controversy) that the scientific uncertainty over the role of population substructure in calculating the chance of DNA matches is too great to pass the so-called Frye test, a measure of scientific acceptance needed for legal acceptability set out in a 1923 decision by the US Supreme Court. As a result, DNA evidence using all but the most conservative statistics is now inadmissible in Massachusetts, some districts of California and Guam.

Although the NAS panel thinks that the use of DNA evidence is appropriate, that message has struggled to get out. A day before the report was to be released, an article in the New York Times characterized its conclusions as striking a blow against DNA evidence. The chair of the panel, Victor McKusick of Johns Hopkins University, denied that interpretation at a hastily scheduled press conference a few hours after the article appeared. Since then, several other articles - most notably a June review by Richard Lewontin of Harvard University in the New York Review of Books - have argued that the NAS panel did not understand the implications of its own report.

The rulings in Massachusetts and California support that argument. The NAS report called for an expanded database drawn from population subgroups and recom- mended, until that exists, the use of a modified 'ceiling' principle in which geneticists would make very conservative judgements on the chance of a certain fingerprint being matched at random. Although the NAS committee did not say that evidence derived from different statistical methods should meanwhile be inadmissible, that is what some courts have concluded.

On 7 August, in People v. Barney, the California court blamed prosecutors for introducing evidence using a 'product rule' calculation that gives an extremely low chance ( 1 in 200 million) of a random match.

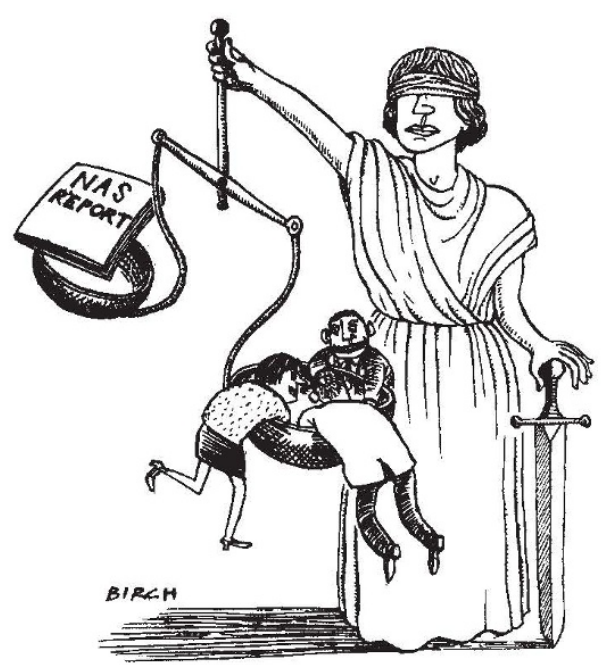

Noting that this technique "has not received general scientific acceptance", the court concluded that "no amount of after-the-fact fine tuning can cure the error, [which] infects the underlying evidence...." On 20 July, in Commonwealth v. Lanigan, the Massachusetts court ruled that "the national call for considered, conservative approaches to DNA testing, such as the use of ceiling frequencies, and the absence of such an approach in the present case underscore the wisdom" of rejecting DNA evidence in an earlier trial.

It is true that several states have accepted DNA evidence since the NAS report, and that several others, including Ohio, have passed legislation explicitly making DNA evidence admissible in paternity cases. But that lack of uniformity existed before the NAS report, and it is disappointing that the report has not resolved it.

For whatever reason, DNA evidence continues to be held to a higher standard than other scientific subjects. That standard, under Frye, requires only "general acceptance" in the scientific community. Yet DNA evidence is often being rejected on the basis of controversies involving a few scientists, including Lewontin, who proclaim themselves to be extremists. (They defend themselves on the grounds that lives are at stake.) Despite the NAS report's endorsement of the fundamental soundness of DNA evidence, its conclusions have apparently been obscured by this debate on the scientific fringe.

"It's clear that the message hasn't gotten through," says Mark Stolorow, manager of forensic services at Cellmark. But courts that have rejected DNA evidence have either misinterpreted parts of the report or focused on side issues, he says; they have not challenged its conclusions.

Much of the problem stems from prosecutors who continue to use methods such as the product rule to come up with extraordinarily low chances of random matches. "There is absolutely no need to come in with statements like "one in a billion", says Philip Reilly, a member of the NAS panel. "One in 10,000 is just as good."

Prosecutors seem to be catching on, however. Stolorow says that Cellmark is receiving an increasing number of requests to calculate DNA match statistics based on the ceiling technique as well as the usual product method. And the Federal Bureau of Investigation has started providing a ceiling calculation to prosecutors who request it, according to John Sylvester, chief of the agency's DNA legal assistance unit.

But more conservative numbers also pose a problem, Stolorow says: many scientists do not believe they provide an accurate measure. Testifying under oath, such a scientist might be forced to give his or her professional opinion on the statistics question. If, in the process of advocating more extreme statistical techniques, an expert witness casts doubt on the NAS report's more conservative conclusions, the DNA evidence could be rejected on the grounds that there is insufficient "scientific agreement" on the issue.

Most people agree that the current confusion is temporary and that the introduction of DNA evidence will someday become routine in the courtroom. But many of the scientists who follow the issue are disappointed that the NAS study did not resolve it. Cellmark wants the panel members to draft a letter discussing - and presumably rejecting - some of the recent court decisions. But the NAS committee has formally disbanded, making that unlikely.

Christopher Anderson 